\title{
Work Culture of Digital Governance Impacting on Citizen Happiness Obtained by Department of Population and Civil Registration of Pariaman City
}

\author{
$1^{\text {st }}$ Wahib Assyahri ${ }^{1}, 2^{\text {nd }}$ Aldri Frinaldi ${ }^{2}$ \\ wassyahri.wa@gmail.com ${ }^{1}$, aldri@ fis.unp.ac.id ${ }^{2}$
}

Department of Magister Public Administration, Universitas Negeri Padang, Padang, Indonesia ${ }^{1,2}$

\begin{abstract}
This study aims to analyze the effect of a work culture based on digital governance on people's happiness in Disdukcapil of Pariaman city. This study used a quantitative approach method. The population in this study was the citizen that obtained the population administration in the Disdukcapil of Pariaman city. The sampling in this study used the Slovin formula with an error rate of 5\% with 323 samples. The determination of sample using was used the Accidental Sampling technique. In collecting data, this study used a questionnaire distributed to respondents with the measurement using a Likert scale. Furthermore, the data obtained were analyzed by using simple linear regression. Thus, the results showed that the work culture variables of digital governance had a significant impact on citizen happiness with a significance value of 0,000 .
\end{abstract}

Keywords: Work Culture; Digital Governance; Citizen Happiness

\section{Introduction}

As a country, Indonesia is obligated to ensure civil's protection and recognition of every important event experienced which shall be entitled to all citizens. Moreover, legal certainty should be provided, including legal presence documents which are also advantageous as clarity of identity and status of civil, providing legal protection and access to services and convenience.

Due to previous factors, the government has issued Law Number 24 of 2013 on Amendments to Law Number 23 of 2006 by Population Administration. The issuance of this law is expected to improve administrative services, especially on population administration. The services should be able to meet the standards of information technology, which are also dynamic, orderly, and non-discriminatory in accomplishing minimum service standards that lead to excellent and comprehensive quality service.

To contribute optimal service, a good work culture is also needed in order to achieve the country's objectives. According to [1] work culture is an understanding, attitude and behavior that are applied while carrying out work in an organization or institution. The values at work as part of work culture can determine the quality of a job performed by a person or a group of people. In other words, the implementation of work culture significantly affects and improves the quality of public services. 
Triguno in [2] stated that work culture is shared values that become traits, habits and giving forces which eventually develop into a culture in the life of a community, group, or organization. Thus, it reflects on attitudes turning into behavior, beliefs, ideas, opinions and actions that are manifested as "work" or "working". Furthermore, Sugiarto in [3] explained work culture as the dominant value that is disseminated in organizations coming from the individuals' work philosophy providing high work discipline. Based on the explanation of the experts above, it can be concluded that work culture is a value of attitudes and behaviors that develop into a culture carrying out work in an organization or agency.

Measurement of good work culture, according to [4] uses six indicators, namely leadership; appearance; awareness of time; communication; awards and recognition; as well as values and beliefs. Furthermore, according to Ivancevich, Lorenzi in [5] work culture includes 1) discipline standards for all employees; 2) a supportive, safe and comfortable physical environment for work; 3) rewards and incentives; 4) High expectations among office communities; 5) harmonious atmosphere among employees. In this case, the work culture is a sector that should be advanced, therefore, the objectives of a country in order to increase general prosperity can be achieved through effective and efficient services. To accomplish a good work culture, digital governance is utilized.

According to [6] Electronic Governance is the application of IT for delivering government services provided as an adjustment to upgrade its interaction with the community and contribute an impact on society. This definition clearly identifies the five dimensions of EGOV, namely government, technology, interaction, customers and society. Furthermore, according to [7] egovernment is a form of e-business along with its processes and structures provided by the government, which is operated by bringing the services closer to the clients including citizens and businesses. The government thereafter collaborates with business partners to carry out electronic transactions within an organizational entity.

In addition, [8] explained e-Governance as reciprocal relationship between the government (state authorities) and the citizens. According to the previous experts, it can be concluded that Electronic Governance is a governance that utilizes IT to advance the relations between businesses, citizens, and other arms of government towards better delivery of government services. At the same time, adopting IT in government operations might simplify the administration and improve public service quality.

In administrative and civil services, the government implements e-Governance which employs technology tools to facilitate work and improve the quality of services in order to achieve effectiveness and efficiency. Therefore, a work culture based on digital governance aims to initiate the interaction process by using technology in achieving a good democratic governance, also, delivering direct services to the public by simplifying the process.

There is also another previous research on work culture of digital governance conducted by [9] titled "Innovation in Government Management Based on Digital Applications in Central Java Province". This paper discusses bureaucratic reform, faced with the challenges of the digital era, in which government officials are required to be able to work in accordance with developments in information technology. The Central Java Provincial Government is developing digital applications in order to support bureaucratic reform, namely the Government Resources Management System (GRMS). The conclusion of this research is that the innovation in government management in the form of a GRMS application has been implemented to assist government administration. However, there are some obstacles were found which are the readiness of the apparatus due to the unfamiliarity with the digital systems, the inadequate role of the application system to support all the needs of government management activities, and the lack of application integration. 
[10] On "Digital workplace and culture: How digital technologies are changing the workforce and how enterprises can adapt and evolve" examines today's growth in technological capabilities. Moreover, this paper also discusses the rapid change increase in computing power available to both consumers and enterprises, and almost omnipresent internet connectivity among other digital advancements which is changing the way employees and companies work. Organizations are benefiting from increased digitization of the workplace through increased productivity, cost savings, a more mobile and agile workforce, and generally increased flexibility and adaptability in an ever increasingly complex market.

Furthermore, [11] on "The Implementation of Electronic Government for Administration of Population Administration Services" discusses the implementation of e-Government in administrative and civil services carrying out by the office of Population and Civil Registry of Serdang Begadai Redency since 2007. The services utilized ICTs such as SIAK and e-KTP in services. There are some benefits found including improved efficiency, effectiveness, transparency, accountability, participation, security, and accuracy of population data. On the other hands, some factors hinder the optimal e-Government such as leaders' commitment, budget, policies, lack of human resources, infrastructure and low levels of public awareness.

Improving service quality through a work culture based on digital governance is supposed to provide not only satisfactory to the community, but also happiness. [12] stated that happiness is a multidimensional construction based on affective well-being, competence, aspirations, autonomy, function and integrative satisfaction. In this context, satisfaction does not equal happiness. Therefore, some negative perceptions of the community arise which is coming from personal experience while receiving services in government agencies. In other words, these negative perceptions occur from the community's experiences as the customers of this service towards the government work culture.

Steel in [13] explained happiness as people's evaluation of their life which includes cognitive assessments of one's life satisfaction in addition to affective evaluations of mood and emotions. Furthermore, happiness is the overall judgment of life that draws on two sources of information: cognitive comparison with the standards of the good life (contentment) and affective information from how one feels most of the time (hardness level of affect) (Veenhoven in [13]).

[14] proposed three dimensions to measure happiness, namely;

1. Comfortable. It is explained as someone's way or point of view to enjoy a beautiful. The indicators are interesting, fresh, and expressive.

2. Peaceful. This is an environmental condition that can create relaxed atmosphere. The indicators are relaxed and lighthearted.

3. Positive action. This action is a reflection of positive thinking or mindset. The indicators are joy, unselfish, and enthusiasm.

Darrin in [15] explained happiness determining by several factors. The first factor is traits which have the tendency to never change highly influenced by genetic elements, culture and experiences early in one's life. Secondly, social comparison is the next factor which according to Easterlin in [15] individuals assess their quality of life not in absolute terms but relatively. This means people constantly comparing themselves to others. The last one is satisfaction needs. According to this theory, happiness is determined by the someone's relationship with the family, health, work, and the amount of money owned which is a basic need for humans.

The Department of Population and Civil Registration (Disdukcapil) of Pariaman City is one of the regional apparatus organizations (OPD). It is operated to provide population, administration services that are accountable, professional, applying information technology, dynamic, orderly, and non-discriminatory. The Disdukcapil of Pariaman City has an important 
role in providing population, administration services, especially documents on population issues. In realizing quality population, administration services, Disdukcapil of Pariaman City has developed a digital governance-based work culture concept, which is providing population, administration services online through the Digi Mobile Dukcapil Application.

Dukcapil Digi Mobile is an android-based application consisting of 11 (eleven) information applications related to online population, administration services provided by the Disdukcapil as a manifestation of a work culture based on digital governance to build community happiness as service recipients. However, this service is not untilized optimally due to the lack of information sharing and government efforts to courage the coummunity, thus, the community has the tendency to choose a traditional or manual service.

Tabel 1 Citizen Preference of Service Delivery

\begin{tabular}{lll}
\hline \multicolumn{1}{c}{$\begin{array}{c}\text { Types of Service } \\
\text { Delivery }\end{array}$} & \multicolumn{1}{c}{ February 2020 } & \multicolumn{1}{c}{ March 2020 } \\
\hline Online & 10 & 16 \\
Manual & 2233 & 2271 \\
Total & 2243 & 2287 \\
\hline Source : Department of Population and Civil Registration of Pariaman City
\end{tabular}

From the table above, it can be seen that in February 2020 only 10 people choose online services $(0.5 \%)$, while the remaining 2233 people had manual services $(99.5 \%)$. Then, in March 2020 , out of a total of 2287 people who got population document services, only 16 people did the online services $(0.7 \%)$, yet the other 2271 people performing manual services $(99.3 \%)$. From these data, it can be concluded that the use of the Dukcapil Digi Mobile application in managing population, administration services has still scantly taken advantage of.

Another research related to digital government work culture on people's happiness was conducted by [16] with the title "Do governance factors matter for happiness in the MENA region?". Furthermore, a study by [17] titled "The influence of green open space and tourismconscious work culture on the happiness of the people in Solok Regency". This research shows that work culture affects people's happiness, if the work culture is bad, then the community does not feel happy with the values of the work culture they do. In other words, there are still some problems found in the work culture of digital government on population, administration services provided by Disdukcapil of Pariaman City which is delivered through the Dukcapil Digi Mobile application.

The formulation of the problems in this research is 1) how is the work culture of employees based on digital governance in the community ?; 2) how is the happiness of the people who take care of population, administration documents at the Disdukcapil Kota Pariaman?; 3) and the main problem in this research is whether there is an influence of work culture based on digital governance on people's happiness in Disdukcapil Kota Pariaman? 


\section{Methodology}

This research uses quantitative methods with associative approach and regression analysis. The population of this study is the citizens who obtain services of population, administration at the Department of Population and Civil Registration or Disdukcapil of Pariaman City during the period of February and March 2020. Slovin formula was used as the sampling method with an error rate of $5 \%$ and produced 323 samples. Determination of the sample using the Accidental Sampling technique. The researcher used the accidental sampling technique because the researcher was researching at the Disdukcapil office of Pariaman City, so whoever the community who meets the author who is doing the service process will be the sample in this study.

Data collection by using a questionnaire distributed to the respondents with Likert scale as the measurement. Then the grid questions in this research questionnaire based were formulated as follows: 
Table 2. The Grid Questions for Questionnaire

\begin{tabular}{|c|c|c|}
\hline Variables & Indicators & Operational Definition \\
\hline \multirow{8}{*}{$\begin{array}{l}\text { Work culture } \\
\text { of digital } \\
\text { governance } \\
\text { (X1) }\end{array}$} & \multirow[t]{2}{*}{ Leadership } & $\begin{array}{l}\text { The persons employed of Disdukcapil guide the } \\
\text { people to utilize the Dukcapil Digi Mobile }\end{array}$ \\
\hline & & $\begin{array}{l}\text { The citizens are able to use Dukcapil Digi } \\
\text { Mobile to get population administration service }\end{array}$ \\
\hline & Appearance & $\begin{array}{l}\text { The design of Digi Mobile application is clear } \\
\text { and interactive } \\
\text { The features of Digi Moblle application are } \\
\text { easy to use and accessible to assist the citizens } \\
\text { in having an online services of population } \\
\text { administration }\end{array}$ \\
\hline & Time awareness & $\begin{array}{l}\text { The service of population administration is } \\
\text { effective and efficient } \\
\text { Disdukcapil provides dependable services }\end{array}$ \\
\hline & \multirow[t]{2}{*}{ Communication } & $\begin{array}{l}\text { The persons employed of Disdukcapil of } \\
\text { Pariaman City do information sharing in public }\end{array}$ \\
\hline & & $\begin{array}{l}\text { The information regarding population } \\
\text { document services is thorough and } \\
\text { comprehensible }\end{array}$ \\
\hline & $\begin{array}{l}\text { Appreciation and } \\
\text { Recognition }\end{array}$ & $\begin{array}{l}\text { I appreciate the innovation to provide online } \\
\text { services for population, administration through } \\
\text { Dukcapil Digi Mobile } \\
\text { I am proud with the efforts made by } \\
\text { Disdukcapil to support population, } \\
\text { administration services through Dukcapil Digi } \\
\text { Mobile }\end{array}$ \\
\hline & Values and Trust & $\begin{array}{l}\text { I admire the population, administration service } \\
\text { through Dukcapil Digi Mobile } \\
\text { The online services of population, } \\
\text { administration through Dukcapil Digi Mobile } \\
\text { are exceptional }\end{array}$ \\
\hline \multirow[t]{4}{*}{$\begin{array}{l}\text { Citizen } \\
\text { Happiness (Y) }\end{array}$} & \multirow[t]{2}{*}{ Comfort } & $\begin{array}{l}\text { Disdukcapil building of Pariaman City is clean } \\
\text { and neat } \\
\text { The waiting room is cozy and tidy }\end{array}$ \\
\hline & & $\begin{array}{l}\text { The employees' appearance is well-presented } \\
\text { and modest. }\end{array}$ \\
\hline & Composure & $\begin{array}{l}\text { The facilitation is equipped and well } \\
\text { maintained } \\
\text { Service processes of population } \\
\text { administration are dependable and orderly }\end{array}$ \\
\hline & Positive Feedback & $\begin{array}{l}\text { The services are excellent and pleasant } \\
\text { I am impressed by the dedicated work done by } \\
\text { the employees of Disdukcapil. }\end{array}$ \\
\hline
\end{tabular}

Source : The results of data processing of 2020 
Then, the validity was obtained from the results of the validity and reliability test to assess its practicability by using Statistical Product and Service Solution (SPSS) program version 25. Furthermore, its validity was determined from the corrected total item correlation with the criteria $\mathrm{r}$ tab $=0.361$ at $\alpha=5 \%$ including pretecting to 30 respondents. On the other hands, the reliability test showed the result to be reliable if it has a Croanbach's Alpha coefficient>0.60.

Thus, descriptive analysis was used which is shown in the form of Total Respondents' Outcomes (TCR). Furthermore, the classical assumption test was conducted to determine the relation between variables, including normality test, heteroscedasticity test and linearity test. After that, the data collected were then processed using the Simple Linear Regression formula.

\section{Findings and Discussion}

\section{1 Results of the Study}

The finding of the first research problem is the overview of the employees' work culture of digital governance and its impact on community or citizens. In general, the results of the study can be seen in the following table. 
Table 3. Variables of Work Culture in Digital Governance

\begin{tabular}{|c|c|c|c|c|}
\hline Explanatory Items & $\mathbf{N}$ & Mean & TCR & Likert Scale \\
\hline $\begin{array}{l}\text { The persons employed by Disdukcapil } \\
\text { guide people to utilize The Dukcapil } \\
\text { Digi Mobile }\end{array}$ & 323 & 3,11 & 77,75 & $\begin{array}{l}\text { Agree } \\
\text { Slightly }\end{array}$ \\
\hline $\begin{array}{l}\text { The citizens are able to use Dukcapil } \\
\text { Digi Mobile to get population } \\
\text { administration service }\end{array}$ & 323 & 3,12 & 78 & $\begin{array}{l}\text { Agree } \\
\text { Slightly }\end{array}$ \\
\hline $\begin{array}{l}\text { The design of Digi Mobile application } \\
\text { is clear and interactive }\end{array}$ & 323 & 3,16 & 79 & $\begin{array}{l}\text { Agree } \\
\text { Slightly }\end{array}$ \\
\hline $\begin{array}{l}\text { The features of Digi Mobile } \\
\text { application are easy to use and } \\
\text { accessible to assist the citizens in } \\
\text { having an online service of population } \\
\text { administration }\end{array}$ & 323 & 3,16 & 79 & $\begin{array}{l}\text { Agree } \\
\text { Slightly }\end{array}$ \\
\hline $\begin{array}{l}\text { The service of population } \\
\text { administration is effective and } \\
\text { efficient }\end{array}$ & 323 & 3,15 & 78,75 & $\begin{array}{l}\text { Agree } \\
\text { Slightly }\end{array}$ \\
\hline $\begin{array}{l}\text { Disdukcapil provides dependable } \\
\text { services }\end{array}$ & 323 & 3,17 & 79,25 & $\begin{array}{l}\text { Agree } \\
\text { Slightly }\end{array}$ \\
\hline $\begin{array}{l}\text { The persons employed of Disdukcapil } \\
\text { of Pariaman City do information } \\
\text { sharing in public }\end{array}$ & 323 & 3,09 & 77,25 & $\begin{array}{l}\text { Agree } \\
\text { Slightly }\end{array}$ \\
\hline $\begin{array}{l}\text { The information regarding population } \\
\text { document services is thorough and } \\
\text { comprehensible }\end{array}$ & 323 & 3,15 & 78,75 & $\begin{array}{l}\text { Agree } \\
\text { Slightly }\end{array}$ \\
\hline $\begin{array}{l}\text { I appreciate the innovation to provide } \\
\text { online services for population, } \\
\text { administration through Dukcapil Digi } \\
\text { Mobile }\end{array}$ & 323 & 3,32 & 83 & Agree \\
\hline $\begin{array}{l}\text { I am proud with the efforts made by } \\
\text { Disdukcapil to support population, } \\
\text { administration services through } \\
\text { Dukcapil Digi Mobile }\end{array}$ & 323 & 3,30 & 82,5 & Agree \\
\hline $\begin{array}{l}\text { I admire the population, } \\
\text { administration service through }\end{array}$ & 323 & 3,24 & 81 & Agree \\
\hline $\begin{array}{l}\text { Dukcapil Digi Mobile } \\
\text { The online services of population, } \\
\text { administration through Dukcapil Digi } \\
\text { Mobile are exceptional }\end{array}$ & 323 & 3,22 & 80,5 & Agree \\
\hline $\begin{array}{l}\text { The approximate scale of work } \\
\text { culture of digital governance }\end{array}$ & 323 & 3,18 & 79,5 & $\begin{array}{l}\text { Agree } \\
\text { Slightly }\end{array}$ \\
\hline
\end{tabular}

Source: Results of Data Processing of 2020 
Based on the table above, it can be seen that the average score of the work culture of digital governance is in agreeing slightly category, as it shows a mean value of 3.18 with a TCR value of $79.5 \%$. Thus, it can be concluded that the people's assessment of the work culture of digital governance of Disdukcapil of Pariaman City is considered moderate in value.

Furthermore, the second problem to be answered through this research is how is the happiness of the people who do the processing of population administration documents at Disdukcapil of Pariaman City? In general, the results of the study show the average score of people's happiness, summarized in the following table:

Table 4. Description of Citizen Happiness Variable

\begin{tabular}{|c|c|c|c|c|}
\hline Explanatory Items & $\mathbf{N}$ & Mean & TCR & Likert Scale \\
\hline $\begin{array}{l}\text { Disdukcapil building of Pariaman City } \\
\text { is clean and neat }\end{array}$ & 323 & 3,28 & 82 & Agree \\
\hline The waiting room is cozy and tidy & 323 & 3,30 & 82,5 & Agree \\
\hline $\begin{array}{l}\text { The employees' appearance is well- } \\
\text { presented and modest. }\end{array}$ & 323 & 3,44 & 86 & Agree \\
\hline $\begin{array}{l}\text { The facilitation is equipped and well } \\
\text { maintained }\end{array}$ & 323 & 3,31 & 82,75 & Agree \\
\hline $\begin{array}{l}\text { Service processes of population, } \\
\text { administration are dependable and } \\
\text { orderly }\end{array}$ & 323 & 3,34 & 83,5 & Agree \\
\hline The services are excellent and pleasant & 323 & 3,32 & 83 & Agree \\
\hline $\begin{array}{l}\text { I am impressed by the dedicated work } \\
\text { done by the employees of Disdukcapil. }\end{array}$ & 323 & 3,30 & 82,5 & Agree \\
\hline $\begin{array}{l}\text { The approximate scale of citizen } \\
\text { happiness }\end{array}$ & 323 & 3,33 & 83,25 & Agree \\
\hline
\end{tabular}

Source : Results of Data Processing of 2020

Based on the table above, it can be seen that the average happiness score of the community is in the agree / high category, because the average happiness of the community shows a mean value of 3.33 with a TCR of $83.25 \%$. Thus, it can be concluded that the happiness of the people who take care of population, administration in the Disdukcapil of Pariaman City is worth agreeing / high.

Furthermore, the classical assumption test was carried out. The classic assumption test in regression research is the first step that must be taken in meeting the requirements of a good regression. The classical assumption tests carried out in this study are: 


\section{Normality Test}

Table 5. The Results of Normality Test

One-Sample Kolmogorov-Smirnov Test

\begin{tabular}{|c|c|c|}
\hline & & $\begin{array}{r}\text { Unstandar } \\
\text { dized Residual }\end{array}$ \\
\hline $\mathrm{N}$ & & 323 \\
\hline \multirow[t]{2}{*}{ Normal Parameters ${ }^{\mathrm{a}, \mathrm{b}}$} & Mean & .0094815 \\
\hline & Std. Deviation & .57534030 \\
\hline \multirow{3}{*}{$\begin{array}{l}\text { Most } \\
\text { Differences }\end{array}$} & Absolute & .072 \\
\hline & Positive & .065 \\
\hline & Negative & -.072 \\
\hline Kolmogorov-Smirnov Z & & 1.289 \\
\hline Asymp. Sig. (2-tailed) & & .072 \\
\hline
\end{tabular}

a. Test distribution is Normal.

b. Calculated from data.

: Based on table 5 above, it is found that the significance value of Asymp. Sig (2-tailed) of $0.072>0.05$, meaning that the residual value of this study is normally distributed. The normality test as one of the prerequisites for conducting the regression test has been fulfilled.

Apart from that, the normality test can also be identified by using graphs of the analyzed data. Data that is normally distributed will form a ball (bell sheped) as shown in the following figure:

Histogram

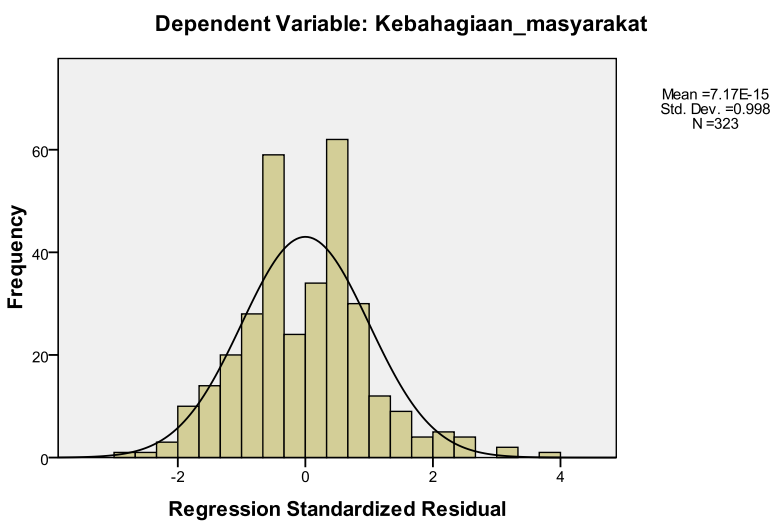

Figure 1. Normality Test

Based on Figure 1 above, it is obtained the results of normality test data showing appropriate data analysis, in other words, the research data passed the normality test. 


\section{Linearity Test}

Linearity test is conducted to determine whether the two variables have a linear significant relationship or not. This test is conducted to fulfill the prerequisites for regression analysis. The Strategic Package for Social Science (SPSS) was used for this test with linearity at the 0.05 . The dependent variable and the independent variable are stated to have a linear relationship if the linearity is more than 0.05 . After the statistical test using SPSS was carried out, the linearity test results were obtained as follows:

Table 6. The Results of Linearity Test ANOVA Table

\begin{tabular}{|c|c|c|c|c|c|c|}
\hline & & & $\begin{array}{l}\text { Sum of } \\
\text { Squares }\end{array}$ & $\begin{array}{l}\text { Mean } \\
\text { Square }\end{array}$ & F & Sig. \\
\hline \multirow{5}{*}{$\begin{array}{l}\text { Unstandardized Residual * } \\
\text { Unstandardized Predicted } \\
\text { Value }\end{array}$} & \multirow{3}{*}{$\begin{array}{l}\text { Between } \\
\text { Groups }\end{array}$} & (Combined) & 78.998173 & \multicolumn{3}{|c|}{.4572 .466 .000} \\
\hline & & Linearity & $.013 \quad 1$ & .013 & .069 & .794 \\
\hline & & $\begin{array}{l}\text { Deviation from } \\
\text { Linearity }\end{array}$ & 78.986172 & \multicolumn{2}{|c|}{.4592 .480} & .000 \\
\hline & \multicolumn{2}{|c|}{ Within Groups } & 27.589149 & .185 & & \\
\hline & \multicolumn{2}{|l|}{ Total } & 106.587322 & & & \\
\hline
\end{tabular}

Based on the test results in table 6 above, it can be seen that the significance value at linearity is 1,000 . As the linearity significance is more than 0.05 , it can be concluded that the work culture variables are influenced by people's happiness.

Simple linear regression is a statistical tool to see the relationship between the independent variable and the dependent variable. In this study, the aim is to find the influence of the work culture of digital governance on citizen happiness. The following are the results of simple linear regression of the data obtained in the study

Table 7. Simpel Linear Regression

\begin{tabular}{llrrrr}
\multicolumn{4}{c}{} & \multicolumn{3}{c}{ Model Summary $^{\mathbf{b}}$} \\
Model & $\mathrm{R}$ & R Square & $\begin{array}{c}\text { Adjusted R } \\
\text { Square }\end{array}$ & $\begin{array}{c}\text { Std. Error of the } \\
\text { Estimate }\end{array}$ \\
\hline 1 & $.618^{\mathrm{a}}$ & .382 & & .380 & .57620
\end{tabular}

a. Predictors: (Constant), work_culture

b. Dependent Variable: citizen_happiness

From table 7, it is found that the value of the work culture variable of digital governance is 0.382 , to put it differently, the work culture variable of digital governance has the influence of $38.2 \%$ of the variable of citizen happiness in the Department of Population and Civil Registration of Pariaman City. While the rest is obtained by other variables outside of this study. 
Table 8. ANOVA ${ }^{b}$

\begin{tabular}{llrrrrr}
\hline Model & & $\begin{array}{c}\text { Sum of } \\
\text { Squares }\end{array}$ & df & Mean Square & F & \multicolumn{1}{l}{ Sig. } \\
\hline 1 & Regression & 65.928 & 1 & 65.928 & 198.573 & $.000^{\mathrm{a}}$ \\
& Residual & 106.575 & 321 & .332 & & \\
& Total & 172.502 & 322 & & & \\
\hline
\end{tabular}

a. Predictors: (Constant), work_culture

b. Dependent Variable: citizen_happiness

The test results in the ANOVA table show a significance value of 0.000 . This indicates that culture has a significant influence on people's happiness. Because the significance of the test value is less than 0.05 , it can be concluded that the magnitude of the influence of digital governance-based work culture on people's happiness is $38.2 \%, 100 \%$ reliable.

\section{2 Discussion}

Based on the research results, it was found that the variable of the work culture of digital governance has a positive and significant influence on the variable of social happiness. It is proved by the results of data processing using SPSS 25 software, that the significance value is $0.000<0.05$.

The amount of influence that the digital governance-based work culture variable has on this citizen happiness variable is $38.2 \%$. The percentage of $38.2 \%$ was obtained based on the value of R Square after the T test was carried out on the third hypothesis which was 0.382 .

Population administration provides the fulfillment of administrative rights, such as public services and protection with respect to population documents for all citizens. The population, administration that is usually performed conventionally has developed into an online management. Through a work culture of digital governance, it is easier to access population, administration services that are more dependable and intact. The citizens are provided with convenient access to obtain population, administration service through Dukcapil Digi Mobile . The files are also enabled to send via post.

Population administration services with the work culture of digital governance gives the impact on the efficiency including time consuming and expenditure. The public can access it through the Digi Mobile Dukcapil application and the service process can be carried out immediately. The fast and straightforward service process will bring satisfaction and happiness for the community as the citizens are no longer required to wait in queue. Therefore, collecting the data of population, administration can be performed properly and advanced. Through this online population, administration service, it might promote the implementation of elections and democracy in the future, which will be conducted online, namely e-voting. In other words, it can be concluded that the work culture of digital governance in population administration services can lead to satisfaction and happiness for the community as the services are effective and efficient.

Current technological developments have affected every aspect of life, including the delivery of public services and other administrative work using online systems such as applications and websites. The results of this study indicate that there is a close relationship with the implementation of digital-based governance in providing better services and information to 
the community, therefore, it can promote citizen happiness as the clients of the services. Disdukapil of Pariaman City has provided numerous services and plenty of information to the public through the Digi Mobile Dukcapil application

The results of this study are in line with research conducted by [17] titled "The influence of green open space and tourism-conscious work culture on the happiness of the people in Solok Regency". The results showed that there was a significant influence of the work culture of tourism sector of happiness of the community in Solok Regency. The significance value of the influence of the conscious tourism sector work culture on citizen happiness is 0.000 , and the influence is $28.3 \%$. Furthermore, [18] stated that happiness can be influenced by culture. Then Darin in [15] explained that one of the factors of happiness, namely traits or traits, where happiness is the nature or character of a person who tends not to change, which is related to culture. It can be concluded that work culture variables based on digital governance can also affect the variable of social happiness.

\section{Conclusion}

Based on the results of this study it can be concluded that 1) people's assessment of a work culture based on digital governance in the Pariaman City Disdukcapil is of medium value, 2) the happiness of the people who take care of population administration in the Kota Pariaman Disdukcapil has a high value, 3 ) there is a significant influence of work culture based on digital governance on people's happiness in the Department of Population and Civil Registration of Pariaman City. The significance value of the influence of digital governance-based work culture on people's happiness is 0,000 and the magnitude of the influence of digital governance-based work culture on the happiness of people who carry out population administration management at the research location is $38.2 \%$. The work culture of digital governance in population, administration services through Dukcapil Digi Mobile is able to bring satisfaction and happiness for the citizens as the services are effective and efficient.

Department of Population and Civil Registration or Disdukcapil should put more attention in sharing the information regarding online population, administration services through the Dukcapil Digi Mobile application to the public, so that people can access the services without difficulty. The online services are also expected to enhance the efficiency of time and expenditure, at the same time, the effectiveness of services provided through application.

\section{References}

[1] A. Frinaldi, "Pengaruh Budaya Kerja Pegawai Negeri Sipil Terhadap Pelayanan Publik Di Dinas Catatan Sipil Dan Kependudukan Kota Payakumbuh," Humanus, vol. 13, no. 2, p. 180, 2014, doi: 10.24036/jh.v13i2.4727.

[2] D. A. N. Arianto, "Pengaruh Kedisiplinan, Lingkungan Kerja Dan Budaya Kerja Terhadap Kinerja Tenaga Pengajar,” J. Econ., vol. 9, no. 2, pp. 191-200, 2013, doi: 10.21831/economia.v9i2.1809.

[3] K. D. N. Anggelina, M. A. Meitriana, and N. Sujana, "Pengaruh Budaya Kerja Terhadap Kinerja Pegawai.," J. Ilm. Santikom, vol. 12, no. 1, pp. 43-48, 2017.

[4] A. Frinaldi, "The Influence of Driver Work Culture and Service Quality on Citizen Satisfaction with Mass Transportation,” vol. 84, no. Iconeg 2016, pp. 450-453, 2017, 
doi: 10.2991/iconeg-16.2017.101.

[5] A. Rahmat, "Pengaruh Kepemimpinan dan Budaya Kerja Dalam Membentuk Komitmen Karywan," J. Ilm. Ekon. dan Bisnis, vol. 12, no. 1, pp. 1-24, 2015.

[6] E. Estevez and T. Janowski, "Electronic Governance for Sustainable Development Conceptual framework and state of research," Gov. Inf. Q., vol. 30, no. SUPPL. 1, pp. S94-S109, 2013, doi: 10.1016/j.giq.2012.11.001.

[7] M. M. Rahman and S. A. Ahsan Rajon, "An effective framework for implementing electronic governance in developing countries: Bangladesh perspective," 14th Int. Conf. Comput. Inf. Technol. ICCIT 2011, no. Iccit, pp. 360-365, 2011, doi: 10.1109/ICCITechn.2011.6164814.

[8] H. Setiawan and P. Santoso, "Model Optimalisasi Peluang Pemanfaatan Media Jejaring Sosial dalam Implementasi E-Governance di Indonesia," J. Inform. UPN "Veteran" Yogyakarta., vol. 2013, no. semnasIF, pp. 147-154, 2013.

[9] A. Sofianto, "Inovasi Manajemen Pemerintahan Berbasis Aplikasi Digital di Provinsi Jawa Tengah," Matra Pembaruan, vol. 3, no. 2, pp. 99-108, 2019, doi: 10.21787/mp.3.2.2019.99-108.

[10] Jennifer Buchanan, B. Kelley, and A. Hatch, "How digital technologies are changing the workforce and how enterprises can adapt and evolve.," Digit. Work. Cult., pp. 1-9, 2016.

[11] Junaidi, "Implementasi Electronic Government Untuk Penyelenggaraan," Reformasi, vol. 5, no. 1, pp. 169-182, 2015.

[12] A. S. Semedo, A. Coelho, and N. Ribeiro, "Authentic leadership, happiness at work and affective commitment," Eur. Bus. Rev., vol. 31, no. 3, pp. 337-351, 2019, doi: 10.1108/ebr-01-2018-0034.

[13] A. Okulicz-Kozaryn, "Happiness research for public policy and administration," Transform. Gov. People, Process Policy, vol. 10, no. 2, pp. 196-211, 2016, doi: 10.1108/TG-07-2015-0030.

[14] A. Frinaldi and A. Khaidir, "Membangun Model Kebijakan Budaya Kerja Sadar Wisata di Kalangan Aparatur dan Masyarakat Pariwisata dalam Upaya Peningkatan Kepuasan Masyarakat Berkunjung ke Lokasi Wisata di Sumatera Barat,” Padang, 2018.

[15] T. Puji Rahayu, "Determinan kebahagiaan di Indonesia," J. Ekon. dan Bisnis, vol. 19, no. 1, pp. 149-170, 2016.

[16] H. Gholipour Fereidouni, Y. Najdi, and R. Ekhtiari Amiri, "Do governance factors matter for happiness in the MENA region?," Int. J. Soc. Econ., vol. 40, no. 12, pp. 1028-1040, 2013, doi: 10.1108/IJSE-11-2012-0208.

[17] V. Yulistia Rahayu, A. Frinaldi, and A. Khaidir, "The influence of green open space and tourism-conscious work culture on the happiness of the people in Solok Regency," IOP Conf. Ser. Earth Environ. Sci., vol. 314, no. 1, 2019, doi: 10.1088/1755-1315/314/1/012053.

[18] Siska Wulandari and Ami Widyastuti, "Faktor - Faktor Kebahagiaan Di Tempat Kerja,” J. Psikol. UIN Sultan Syarif Kasim Riau, vol. 10, no. Juni, pp. 41-52, 2014. 